\title{
KONSTRUKSI PUTUSAN PENGADILAN HUBUNGAN INDUSTRIAL DALAM MEMBERIKAN PERTIMBANGAN HUKUM DENGAN ALASAN DISHARMONIS
}

\author{
Mohammad Fandrian Adhistianto, Erma Hari Alijana \\ Fakultas Hukum Universitas Pamulang \\ E-mail : mohammadfaandrianhadistianto@gmail.com
}

\begin{abstract}
Abstrak
Latar belakang Penelitian ini yaitu mengkaji lebih jauh putusan Pengadilan Hubungan Industrial dalam pertimbangan hukum disharmonis sebagai alasan PHK. Seringkali terjadi kasus perselisihan PHK dimana Majelis Hakim memutus alasan yang digunakan oleh Pengusaha dalam melakukan upaya PHK tidak terbukti, namun selanjutnya justru Majelis Hakim yang menentukan PHK dengan alasan disharmonis. Persoalan ini sering kali terjadi pada setiap perkara perselisihan PHK, walaupun sebenarnya UUK tidak mengatur mengenai alasan PHK dengan alasan disharmonis. Selain itu dengan banyaknya putusan-putusan seperti tersebut di atas setidaknya terlihat bahwa hak atas kepastian kerja yang seharusnya dimiliki oleh setiap pekerja/ buruh, dan merupakan amanat dari bentuk perlindungan sebagaimana telah diatur dalam UUK tidak dapat terwujud dikarenakan pertimbangan dari Majelis Hakim semata. Hasil penelitian ini yaitu implementasi dishanrmonis sebagai dasar PHK oleh PHI pada Pengadilan Negeri maupun MA tidak mencerminkan dilaksanakannya asas kepastian kerja yang merupakan hak dasar Pekerja
\end{abstract}

Kata Kunci : diharmonis; putusan; perburuhan.

\begin{abstract}
The author's background for writing this study is to further study the "Disharmonic Polemic as a Reason in the Decision Regarding Termination of Employment (Overview of Theory of the Rule of Law and Heteronomic Labor Law). There are often cases of work termination disputes where the Panel of Judges decides the reasons used by the Employer in making the termination of employment are not proven, but then the Panel of Judges determines the termination of employment based on disharmonical reasons. This problem often occurs in every case of termination of employment disputes, even though Act No. 13 year 2003 does not regulate the reasons for termination of employment for disharmonical reasons. In addition, with the many decisions as mentioned above, at least it can be seen that the right to work certainty that should be owned by every worker / laborer, and is mandated from the form of protection as regulated in Law Number 13 Year 2003 cannot be realized because consideration of the Panel of Judges only. The results of this study are the implementation of dishanrmonis as a basis for layoffs by the Industrial Relations Court in the District Court and the Supreme Court of the Republic of Indonesia does not reflect the implementation of the principle of work certainty which is the basic right of workers
\end{abstract}


Keywords: disharmonist; verdict; labour.

\section{Pendahuluan}

Semenjak Undang-Undang Nomor 2 Tahun 2004 Tentang Penyelesaian Perselisihan Hubungan Industrial berlaku mengakibatkan perselisihan PHK menjadi kewenangan absolut PHI pada Pengadilan Negeri untuk tingkat pertama, dan Majelis Hakim MA pada tingkat terakhir. Perselisihan PHK merupakan perselisihan yang kerap terjadi di dunia ketenagakerjaan, jika dibandingkan dengan jenis perselisihan hubungan industrial lainnya. ${ }^{1}$

Seringkali terjadi kasus perselisihan PHK dimana Majelis Hakim memutus alasan yang digunakan oleh Pengusaha dalam melakukan upaya PHK tidak terbukti, namun selanjutnya justru Majelis Hakim yang menentukan PHK dengan alasan disharmonis. Persoalan ini sering kali terjadi pada setiap perkara perselisihan PHK, walaupun sebenarnya Undang-Undang Nomor 13 Tahun 2003 Tentang Ketenagakerjaan tidak mengatur mengenai disharmonis sebagai alasan PHK. Selain itu dengan banyaknya putusan-putusan seperti tersebut di atas setidaknya terlihat bahwa hak atas kepastian kerja yang seharusnya dimiliki oleh setiap pekerja/ buruh, dan merupakan amanat dari UUK tidak dapat terwujud dikarenakan pertimbangan dari Majelis Hakim semata. Terlebih dari itu, menjadi penyebab terganggunya rasa keadilan bagi pekerja/ buruh yang menjadi pihak dalam perkara tersebut

Terjadinya persoalan tersebut di atas merupakan latar belakang Penulis untuk menulis Penelitian ini untuk mengkaji lebih jauh mengenai "Konstruksi Putusan Pengadilan Hubungan Industrial Dalam Memberikan Pertimbangan Hukum Dengan Alasan Disharmonis”

\section{Permasalahan}

Latar belakang di atas menjadi dasar dalam merumuskan permasalahan hukum yaitu: Pertama, bagaimana $\mathrm{PHI}$ mengkonstruksikan pertimbangan hukum mengenai disharmonis sebagai alasan PHK? Kedua, bagaimana implementasi asas kepastian kerja terhadap dishamronis sebagai alasan pemutusan hubungan kerja?

${ }^{1}$ Andari Yurikosari dan Yolanda Pracelia, Analisis Putusan Sela Terhadap Permohonan Pembayaran Upah Proses Dalam Pengadilan Hubungan Industrial (Studi Putusan: Putusan Pengadilan Hubungan Industrial Nomor: 181/Pdt.Sus-Phi/2016/Pn.Bdg Jo Putusan Pengadilan Hubungan Industrial Nomor: 82/Pdt.Sus-Phi/2016/Pn.Bdg), Jurnal Hukum Adigama, Vol. 2 No. 1 tahun 2019, Universitas Tarumanegara, hlm. 2. 


\section{Metode Penelitian}

Dalam tulisan ini Peneliti menggunakan Penelitian Hukum Normative ${ }^{2}$ didasarkan pada kajian secara komprehensif terhadap Asas Kepastian Kerja yang telah diamanatkan dalam UUD 1945, Naskah proses pembentukan dan pengesahan UUK, dan UUK disandingkan dengan Putusan Pengadilan baik dari tingkat PHI maupun MA yang telah Penulis inventaris. Pendekatan analisis normatif terhadap bahan-bahan tersebut di atas bertujuan agar Penulis dapat menyimpulkan apakah dalam Putusan Pengadilan baik pada tingkat PHI maupun MA yang memutus PHK dengan alasan PHK telah menerapkan Asas Kepastian Kerja.

\section{Pembahasan}

Perselisihan Hubungan Industrial Mengkonstruksikan Pertimbangan Hukum Mengenai Disharmonis Sebagai Alasan Pemutusan Hubungan Kerja

Indonesia telah mengakui adanya hak atas pekerjaan sebagaimana yang telah diatur dalam ketentuan Pasal 27 ayat (2) UUD 1945. Lebih lanjut diatur dalam Pasal 38 Undang-Undang Nomor 39 Tahun 1999 Tentang Hak Asasi Manusia. Oleh karena itu hak atas pekerjaan telah dijamin oleh konstitusi Negara, dan Negara Indonesia wajib untuk memenuhinya. Oleh karena itu segala kebijakan-kebijakan baik berupa Undang-Undang (legistative policy) dan peraturan perundang-undangan dibawahnya (bureaucracy policy) tidak boleh bertujuan untuk mengurangi substansi dari hak konstitusional ${ }^{3}$.

Hak-hak konstitusi yang dimiliki oleh Pekerja selanjutnya diterjemahkan dalam UUK sebagai bentuk dari Hukum Perburuhan Heteronom yang berlaku di Indonesia. Undang-undang ini pula merupakan bentuk nyata intervensi Pemerintah dalam konteks Hukum Perburuhan. Secara umum orientasi UUK adalah dapat dilihat pada Pasal 4 UUK. Dalam sejarah pembentukannya UUK ini diajukan oleh Pemerintah pada tahun 2000 dengan judul awal yaitu Rancangan Undang-Undang Tentang Pembinaan dan Perlindungan Ketenagakerjaan. ${ }^{4}$ Ratio Legis dari RUU ini menurut Pemerintah pada waktu itu yaitu perwujudan hak asasi manusia yang dalam hal ini yaitu hak dasar pekerja. Hal ini kiranya menjadi benar karena kedudukan pekerja pada hakikatnya jika ditinjau dari segi struktural wajib dilindungi oleh negara

${ }^{2}$ Soerjono Soekanto dan Sri Mamudji, Penelitian Hukum Normatif: Suatu Tinjauan Singkat, RajaGrafindo Persada, Jakarta, 2001, hlm. 23

${ }^{3}$ Mustari dan A. Nuruliah M., Hak Atas Pekerjaan Dan Upah Yang Seimbang, SUPREMASI : Jurnal Pemikiran, Penelitian Ilmu-Ilmu Sosial, Hukum dan Pengaajarannya, Vol. 11 No. 1 tahun 2016, Universitas Negeri Makasar, hlm. 113

${ }^{4}$ Surat Presiden Republik Indonesia Nomor R.11/PU/V/2000 Perihal : Rancangan Undang-Undang Tentang Pembinaan dan Perlindungan Ketenagakerjaan, tertanggal $8 \mathrm{Mei}$ 2000. 
untuk menghindari praktek perbudakan, dimana perlindungan tersebut diwujudkan oleh Negara dalam bentuk undang-undang. ${ }^{5}$ Peran negara dalam konteks Indonesia dalam mewujudkan hubungan industrial yang harmonis mengacu dasar filosofi bangsa yaitu Pancasila. ${ }^{6}$

Namun pada faktanya setelah melalui proses pembahasan di DPR RI, RUU ini mengalami degradasi perihal peran Negara dalam melindungi pekerja, dan telah disahkan sebagaimana UUK yang sampai denagan saat ini berlaku. Hal ini dibuktikannya dengan banyak pasal dalam UUK yang merupakan penerapan dari Fleksibilitas Pasar Pekerja (Flexibility Labour Market). Penerapan Fleksibilitas Pasar Pekerja ini akan mengakibatkan tergredasinya hak-hak dasar pekerja sehingga justru menyebabkan terabaikannya amanat yang ada dalam UUD 1945, sedangkan bagi pengusaha membuat kepastian keberlangsungan usaha yang dilakukan. ${ }^{7}$ Khusus dalam Penelitian ini, Peneliti akan memfokuskan pada perlindungan hukum hak atas pekerjaan dengan kaitannya terjadinya PHK. Perlindungan hukum yang dimaksud merupakan perlindungan yang diberikan terhadap pekerja oleh Negara guna mewujudkan keadilan, ketertiban, kepastian, kemanfaatan dan kedamaian. ${ }^{8}$

Dalam UUK mengatur mengenai alasan-alasan untuk seorang pekerja dapat dilakukan PHK, seperti halnya PHK dengan alasan mengundurkan diri, tidak lulus masa percobaan, selesainya jangka waktu PKWT, pelanggaran Perjanjian Kerja, Peraturan Perusahaan, PKB, pailit, efisiensi, dan lainnya. Namun menurut penelurusan Penulis terhadap UUK sama sekali tidak ditemukannya disharmonis sebagai alasan yang dapat digunakan dalam melakukan PHK kepada Pekerja dalam batang tubuh UUK. Menurut Juanda Pangaribuan alasan disharmonis didasarkan pada pemahaman prinsip dalam hubungan kerja yaitu hubungan yang harmonis dan berkeadilan untuk mewujudkan kelangsungan bekerja dan berusaha. Harmonisasi dalam hubungan kerja merupakan dasar menciptakan suasana tenang, aman, dan nyaman dalam bekerja. ${ }^{9}$. Namun pada faktanya dapat dilihat dalam putusan-

\footnotetext{
${ }^{5}$ Heru Suyanto dan Andriyanto Adhi Nugroho, Perlindungan Hukum Terhadap Hak-Hak Pekerja Outsourcing Berdasarkan Asas Keadilan, Jurnal Yuridis, Vol. 3 No. 2 tahun 2016, Universitas Pembangunan Nasional "Veteran" Jakarta, hlm. 5.

${ }^{6}$ Kunia Maharani, Peran Negara Dalam Mewujudkan Hubungan Industrial Pancasila Yang Harmonis Menuju Kesejahteraan Pekerja, Proceeding Fakultas Ekonomi, 2013,Universitas STIKUBANK, hlm. 17.

${ }^{7}$ Asep Ahmad Saefuloh, Kebijakan Outsourcing Di Indonesia : Perkembangan Dan Permasalahan, Jurnal Ekonomi \& Kebijakan Publik, tahun 2011, DPR RI, hlm. 347.

${ }^{8}$ Annisa Fitria, Perlindungan Hukum Terhadap Pekerja Atau Buruh Yang Terkena PHK Akibat Efisiensi Di Perusahaan, Lex Jurnalica, Vol 15 No. 3 tahun 2018, Universitas Esa Unggul, hlm. 328.

9 Juanda Pangaribuan, Tuntutan Praktis Penyelesaian Perselisihan Hubungan Industrial, PT Bumi Intitama Sejahtera, Jakarta, 2010, hlm. 1.
} 
putusan baik pada tingkat PHI maupun MA, disharmonis kerap kali justru dipergunakan oleh Hakim untuk memutus hubungan kerja walaupun alasan PHK yang menjadi alasan secara hukum tidak terbukti. Menurut Penulis yang sepakat sebagaimana pendapat Juanda Pangaribuan yang menyatakan disharmoni sesungguhnya didasarkan pada suatu kebencian/ ketidaksukaan yang dapat berujung pada mutasi, demosi, atau PHK. ${ }^{10}$ Menjadi pertanyaan bagi Penulis apakah seorang Pekerja yang di lakukan PHK oleh Pengusaha dengan didasarkan pada suatu alasan tertentu, namun tidak terbukti secara hukum tetap dapat di PHK oleh Hakim dengan alasan disharmonis? Pertanyaan kunci tersebut akan Penulis jabarkan pada pembahasan berikutnya.

Perselisihan hubungan industrial yang dulu dikenal dengan istilah perselisihan perburuhan pada umumnya merupakan perselisihan yang berawal dari ketidaksepahamannya mengenai penerapan hukum, atau tuntutan para pekerja terhadap kesejahteraan mereka. UU no 22 /1957 mengelompokan perselisihan perburuhan menjadi 2 (dua) kategori, yaitu: ${ }^{11}$

1. Persellisihan Perburuhan Kolektif, yaitu perselisihan antara majikan dengan serikat buruh yang disebabkan tidak adanya kesepahaman dalam hal hubungan kerja, syarat-syarat kerja dan/ atau keadaan perburuhan;

2. Perselisihan Perburuhan Perorangan, yaitu perselisihan antara majikan dengan buruh non anggota serikat buruh.

Berdasarkan 2 (dua) kategori perselisihan perburuhan pada masa keberlakuan UU no 22 / 1957, dan UU no 12 /1964, dikaitkan dengan perselisihan PHK dapat diambil kesimpulan bahwa terdapat perbedaan penggunaan dasar hukum terhadap perselisihan PHK yang melibatkan pekerja non anggota Serikat Buruh dengan yang melibatkan pekerja anggota Serikat Buruh secara massal. Hal ini telah berubah saat mulai berlakunya UU PPHI. Secara sederhana dapat Penulis katakan sejak berlakunya UU PPHI khususnya definisi mengenai Perselisihan PHK, telah meniadakan perbedaan penggunaan dasar hukum terhadap PHK yang dilakukan baik kepada pekerja perseorangan dengan massal, dan anggota maupun yang non anggota Serikat Buruh.

Namun berubahnya aturan pengkategorian mengenai PHK ini, tidak dapat merubah dampak riil yang dialami oleh Pekerja yang ter PHK. Tujuan dari seorang bekerja adalah untuk mendapatkan upah guna menghidupi diri dan keluarganya, maka saat terhentinya hubungan kerja maka secara otomatis akan berhenti pula upah sehingga akan mengakibatkan keberlangsungan hidup pekerja dan keluarganya. Selain dari itu, seorang bekerja bertujuan pula

${ }^{10}$ Ibid.

${ }^{11}$ Hartono Widodo dan Judiarto, Segi Hukum Penyelesaian Perselisihan Perburuhan, Rajawali, Jakarta, 1992, hlm. 25-26. 
untuk mendapatkan dan meningkatkan karirnya. Penulis sependapat dengan Penjelasan Umum UU no 12 / 1964 menyatakan

"Putusnya hubungan kerja berarti permulaan masa pengangguran dengan segala akibatnya, sehingga untuk menjamin kepastian dan ketenteraman hidup kaum buruh seharusnya tidak ada PHK."

Kiranya amanat untuk menjadikan PHK sebagai upaya terakhir dapat dilihat dalam ketentuan Pasal 151 UUK. Pasal tersebut mengamanatkan setidaknya terdapat 3 (tiga) tahapan dalam hal perselisihan PHK yaitu seluruh pihak dengan segala upaya haruslah didasarkan pada itikad baik harus melaksanakan hubungan kerja yang positif dan menghindari hal-hal yang akan mengakibatkan terjadinya sebuah perselisihan. Berikutnya bilamana perselisihan menjadi tidak mungkin untuk dihindarkan maka kehendak untuk melakukan PHK haruslah dirundingkan oleh para pihak. Terakhir, PHK hanya dapat dilakukan dengan putusan pengadilan yang telah incrhat. ${ }^{12}$

\section{Implementasi Asas Kepastian Kerja Terhadap Dishamronis Sebagai Alasan Pemutusan Hubungan Kerja}

Dalam tulisan ini, Penulis telah menginventaris dan menganalisis terhadap Putusan-Putusan baik pada tingkat PHI maupun MA terkait penggunaan disharmonis sebagai alasan PHK. Secara lengkap, berikut putusanputusan tersebut:

1. Putusan MA No. Perkara : $131 \mathrm{~K} / \mathrm{Pdt}$.Sus-PHI/2016 jo. Putusan PHI pada Pengadilan Negeri Medan No. Perkara :155/Pdt.Sus-PHI/2015/PN.Mdn

Pada pokoknya dalam pertimbangan hukum Hakim Kasasi pada perkara ini menyatakan:

"Bahwa hubungan kerja antara Penggugat dengan Tergugat tidak harmonis lagi untuk dilanjutkan, yang mana disebabkan karena PHK terhadap Pemohon KasasilPenggugat tanpa adanya kesalahan, sehingga patut bagi Termohon Kasasi/Tergugat dihukum untuk memberikan Pesangon 2 (dua) kali Pasal 156 Undang Undang Nomor 13 Tahun 2003 tentang Ketenagakerjaan;"

2. Putusan PHI pada Pengadilan Negeri Bandung Perkara No: 252/Pdt.SusPHI/2018/PN.Bdg.

Pada pokoknya dalam pertimbangan hukum Hakim PHI pada Pengadilan Negeri Bandung pada perkara ini menyatakan:

${ }^{12}$ Agusmidah, et.all, Bab-Bab Tentang Hukum Perburuhan Indonesia, Pustaka Larasan, Denpasar, 2012, hlm. 56. 
"Menimbang, bahwa berdasarkan pertimbangan hukum tersebut di atas, dimana dalam perkara a quo Pengguat sudah tidak menghendaki lagi hubungan kerjanya tetap berlangsung dengan Tergugat, oleh karenanya Majelis Hakim berpendapat apabila hubungan kerja antara Penggugat dan Tergugat dilanjutkan maka tidak akan memberikan kemanfaatan bagi keduanya, dan dengan mempertimbangkan asas kemanfaatan bagi kedua belah pihak serta pula mengakomodir petitum Penggugat tentang mohon putusan yang seadil-adilnya (es aequo et bono), sehingga berdasarkan pertimbangan-pertimbangan tersebut di atas, maka sudah sepatutnya terhadap hubungan kerja antara Penggugat dengan Tergugat untuk diakhiri dan dinyatakan putus sejak putusan ini diucapkan;"

3. Putusan MA Perkara No: 743 K/Pdt .Sus/2010 jo. Putusan PHI pada Pengadilan Negeri Tanjung Pinang Perkara No: 42/G/2009/PHI .PN.TPI

Pada pokoknya dalam pertimbangan hukum Hakim Kasasi pada perkara ini menyatakan:

"Bahwa pekerja telah diputuskan oleh Judex Facti untuk bekerja kembali, demi sosial jika dilanjutkan hubungan kerja akan bisa menimbulkan disharmonis, maka untuk itu pekerja di PHK dengan diberi kompensasi 2 kali sebagaimana yang diatur dalam Pasal 156 ayat (2) , (3) \& (4) Undang- Undang No. 13 Tahun 2003;”

4. Putusan MA Perkara No: 502 K/Pdt.Sus/2009 tanggal 15 Juni 2010.

Pada pokoknya dalam pertimbangan hukum Hakim Kasasi pada perkara ini menyatakan

“....berdasarkan alinea III Penjelasan Umum UU No 2 Tahun 2004, Judex Factie seharusnya menyatakan hubungan kerja putus......dst"

5. Putusan MA Perkara No: 225 K/Pdt. Sus/2011 tanggal 15 Juni 2010. Pada pokoknya dalam pertimbangan hukum Hakim Kasasi pada perkara ini menyatakan

"Bahwa hubungan kerja antara Penggugat dengan Tergugat sudah tidak harmonis dengan adanya PHK oleh Tergugat dan ditindak lanjuti dengan Surat Skorsing; Bahwa sesuai dengan Penjelasan UU no 2 Tahun 2004, yaitu apabila salah satu pihak tidak menghendaki lagi untuk terikat hubungan kerja, maka sulit bagi para pihak untuk mempertahankan hubungan kerja yang harmonis;

Bahwa berdasarkan pertimbangan tersebut di atas, untuk kemanfaatan kedua belah pihak, maka adil hubungan kerja putus dengan alasan disharmonis;" 
6. Putusan MA Perkara No: 743 K/Pdt.Sus/2010 jo. Putusan PHI pada Pengadilan Negeri Tanjung Pinang Perkara No: 42/G/2009/PHI.PN.TPI. tanggal 3 Maret 2010. Pada pokoknya dalam pertimbangan hukum Hakim Kasasi pada perkara ini menyatakan

"Pekerja telah diputuskan oleh judex factie untuk bekerja kembali, demi social jika dilanjutkan hubungan kerja akan bisa menimbulkan disharmonisasi......"

Putusan-putusan tersebut membuktikan pada faktanya disharmonis secara nyata digunakan baik PHI maupun MA sebagai dasar PHK walaupun alasan PHK yang diajukan oleh Pengusaha menurut hukum tidak terbukti. Terdapat alasan-alasan yang dapat Penulis inventaris yang mendasari Hakim baik pada PHI maupun MA, yaitu: Asas manfaat kalau hubungan kerja tetap dipertahankan tidak akan memberikan kemanfaatan bagi keduanya; Perspektif sosial akan menimbulkan disharmonis; Berdasarkan alinea III Penjelasan Umum UU PPHI.

Penulis tidak sependapat disharmonis yang dapat dijadikan dasar oleh PHK, terlebih apabila alasan PHK yang diajukan oleh Pengusaha tidak terbukti secara hukum. Pertama, Indonesia saat ini merupakan Negara yang bersifat Negara Kesejahteraan dimana diwajibkannya Negara untuk hadir dan aktif melindungi pihak yang lemah secara structural melalui produk hukum yang bernama peraturan perundang-undangan. Perlindungan yang dimaksud dalam hal ini adalah perlindungan atas kepastian kerja yang wajib dimiliki oleh Pekerja saat PHK yang diajukan kepadanya tidak terbukti secara hukum. Walaupun UUK tidak ada satupun pasal yang menjamin pekerja untuk dipekerjakan kembali pada pekerjaan dan posisinya seperti semula, namun harusnya dapat dipahami bahwa ratio legis dari UUK sendiri adalah perlindungan Negara kepada pekerja. Maka dari itu Pengadilan sebagai bagian dari Negara yang memiliki fungsi sebagai Lembaga Yudikatif harusnya memastikan pekerja untuk dipekerjakan kembali jika alasan PHK yang diajukan oleh Pengusaha tidak dapat dibuktikan oleh hukum guna mewujudkan asas kepastian kerja dan bekerja.

Kedua, secara formil Hakim baik pada tingkatan PHI maupun MA terikat pada ketentuan Pasal 100 UU PPHI. Putusan harus didasarkan pada hukum, perjanjian yang ada, kebiasaan, dan keadilan. Dari beberapa putusan yang telah diinventaris oleh Penulis tersebut di atas, didapat bahwa Hakim memutus PHK disharmonis menggunakan petitum sekunder dalam gugatan yaitu ex aequo et bono, dengan kata lain Hakim berusaha untuk menerapkan keadilan. Dalam membahas ini perlu diingat pula bahwa disharmonis tidak dikenal atau diatur secara jelas dalam batang tubuh UUK . Sebagaimana yang telah dijelaskan sebelumnya Hakim terikat pada ketentuan Pasal 100 UU PPHI 
bersifat kumulatif, dan bukan fakultatif. Hal ini berarti hukum, perjanjian yang ada kebiasaan, dan keadilan haruslah menjadi satu kesatuan yang wajib dipertimbangkan oleh Hakim, dan tidak bisa hanya keadilan saja. Penerapan disharmonis sebagai alasan PHK oleh Hakim menurut Penulis merupakan kewenangan Hakim dalam menemukan hukum (rechtvinding), dikarenakan UUK tidak mengatur disharmonis sebaagai alasan PHK. Kewenangan ini didasarkan pada ketentuan di dalam Pasal 10 ayat (1) UU No. 48 /2009 juncto Pasal $22 \mathrm{AB} .{ }^{13}$ Namun dalam menerapkan kebebasan hakim menggunakan kewenangan rechtvinding hakim dibatasi oleh: 14 "Larangan untuk mengesampingkan tuntutan (petitum; Pengaturan Pasal 178 ayat (3) HIR"

Menurut Yahya Harahap ${ }^{15}$, putusan yang didasarkan pada petitum ex aequo et bono tidak boleh melebihi substansi petitum primair sebagaimana ketentuan Pasal 178 ayat (3) HIR, dan putusan tersebut tidak boleh merugikan salah satu pihak. Berdasarkan Yurisprudensi Mahkamah Agung No. 140 K/Sip/1971, tanggal 12 Agustus 1972, menyebutkan kaidah "Putusan hakim yang mengabulkan ex aequo et bono harus masih terkait dalam kerangka petitum primair". Oleh karena itu tidak tepat apabila amar putusan atas tuntutan subsidair melebihi dari hal-hal yang tidak dituntut oleh penggugat dalam petitum primairnya. Dalam tulisan ini disharmonis sebagai alasan PHK yang dikabulkan oleh Hakim walaupun alasan PHK yang diajukan telah tidak terbukti oleh hukum, menurut Penulis merupakan putusan yang bersifat ultra petita karena hal-hal sebagai berikut: Putusan PHK disharmonis oleh Hakim jelas melebihi dari Posita maupun Petitum gugatan; Merugikan salah satu pihak, yang dalam hal ini pekerja karena pekerja pasti mengalami kerugian berupa hilangnya kepastian kerja yang mengancam keberlangsungan kehidupan diri dan keluarganya.

Ketiga, pada faktnya saat ini untuk dapat kembali mencari dan mendapatkan pekerjaan merupakan hal yang sulit, terlebih Negara tidak memberikan jaminan untuk pekerja yang ter PHK bisa segera mendapatkan kembali pekerjaan. Hal ini didasari pada faktor umur, dimana pada umumnya pekerja yang ter PHK dengan alasan disharmonis telah memiliki masa kerja yang cukup lama, sehingga umur pekerja sudah melebihi dari batasan umur yang dicari dan dibutuhkan oleh perusahaan lain untuk masuk dan mendapatkan kerja kembali. Terlebih apabila pekerja yang ter PHK yang nota bene merupakan pengurus Serikat Pekerja yang aktif mengkritisi dan menuntut kenaikan kesejahteraan bagi pekerja lainnya. Suka atau tidak suka,

${ }^{13}$ Bambang Sugeng Ariadi, et. all, Kajian Penerapan Asas Ultra Petita Pada Petitum Ex Aequo Et Bono, Yuridika, Vol 29 No. 1 tahun 2014, Universitas Airlangga, hlm. 104.

14 ibid

${ }^{15}$ M. Yahya Harahap, Hukum Acara Perdata, Sinar Grafika, Jakarta, 2005, hlm. 67. 
pada faktanya track record seorang pekerja yang merupakan pengurus serikat pekerja lebih sulit untuk mendapatkan pekerjaan baru, karena saat ini terdapat paradigm buruh yang terbentuk di Perusahaan terhadap Serikat Pekerja maupun pengurus Serikat Pekerja. Berdasarkan faktor-faktor ini, jelas alih-alih bisa segera mendapatkan pekerjaan baru, yang terjadi adalah pekerja tersebut terpaksa menjadi pengangguran. Kalo ditilik dari hal ini, seharusnya menjadi perhatian serius bagi Pemerintah, karena pengurangan pengangguran merupakan arah pembangunan Indonesia dari tahun ke tahun.

\section{Penutup}

\section{Simpulan}

Pemutusan Hubungan kerja pada Pengadilan Negeri dan Mahkamah Agung mengkonstruksikan pertimbangan hukum mengenai disharmonis didasarkan pada tidak terbuktinya secara hukum alasan Pemutusan Hubungan Kerja yang diajukan oleh Pengusaha kepada Pekerja, namun dengan dasar materiil Asas Manfaat dan alinea III Penjelasan UU PPHI, dan dasar formil tuntutan sekunder (ex aquo et bono) dalam sebuah gugatan. implementasi disharmonis sebagai dasar Pemutusan Hubungan kerja oleh Perselisihan Hubungan Industrial pada Pengadilan Negeri maupun Mahkamah Agung tidak mencerminkan dilaksanakannya asas kepastian kerja yang merupakan hak dasar Pekerja.

\section{Saran}

Menurut Penulis diperlukannya revisi terhadap UUK khusus dimasukannya sebuah pasal yang mengatur mengenai kewajiban pengusaha untuk mempekerjakan kembali Pekerja yang alasan diajukannya PHK tidak terbukti secara hukum. Dengan adanya aturan yang secara jelas akan membuat sebuah kepastian hukum atas hubungan kerja baik pekerja maupun pengusaha. Kedua, selain itu diperlukannya juga sosialisasi dan kesepahaman hakim dari Mahkamah Agung Republik Indonesai dan PHI mengenai Yurisprudensi Mahkamah Agung sebagai salah satu sumber hukum yang telah secara jelas mengatur mengenai batasan-batasan dalam Hakim menggunakan kewenangan dan kebebasannya menggunakan petitum sekunder sebagai dasar membuat pertimbangan dan amar putusan perselisihan PHK. 


\section{Daftar Pustaka}

\section{Buku}

Agusmidah, et.all, Bab-Bab Tentang Hukum Perburuhan Indonesia, Pustaka Larasan, Denpasar, 2012.

Hartono Widodo dan Judiarto, Segi Hukum Penyelesaian Perselisihan Perburuhan, Rajawali, Jakarta, 1992.

Juanda Pangaribuan, Tuntutan Praktis Penyelesaian Perselisihan Hubungan Industrial, PT Bumi Intitama Sejahtera, Jakarta, 2010.

M. Yahya Harahap, Hukum Acara Perdata, Sinar Grafika, Jakarta, 2005.

Soerjono Soekanto dan Sri Mamudji, Penelitian Hukum Normatif: Suatu Tinjauan Singkat, RajaGrafindo Persada, Jakarta, 2001.

\section{Jurnal}

Andari Yurikosari dan Yolanda Pracelia, "Analisis Putusan Sela Terhadap Permohonan Pembayaran Upah Proses Dalam Pengadilan Hubungan Industrial (Studi Putusan: Putusan Pengadilan Hubungan Industrial Nomor: 181/Pdt.Sus-Phi/2016/Pn.Bdg Jo Putusan Pengadilan Hubungan Industrial Nomor: 82/Pdt.Sus-Phi/2016/Pn.Bdg)", Jurnal Hukum Adigama, Vol. 2 No. 1 tahun 2019, Universitas Tarumanegara.

Annisa Fitria, "Perlindungan Hukum Terhadap Pekerja Atau Buruh Yang Terkena PHK Akibat Efisiensi Di Perusahaan”, Lex Jurnalica, Vol 15 No. 3 tahun 2018, Universitas Esa Unggul.

Asep Ahmad Saefuloh, "Kebijakan Outsourcing Di Indonesia : Perkembangan Dan Permasalahan”, Jurnal Ekonomi \& Kebijakan Publik, tahun 2011, DPR RI.

Bambang Sugeng Ariadi, et. all, "Kajian Penerapan Asas Ultra Petita Pada Petitum Ex Aequo Et Bono”, Yuridika, Vol 29 No. 1 tahun 2014, Universitas Airlangga.

Heru Suyanto dan Andriyanto Adhi Nugroho, "Perlindungan Hukum Terhadap Hak-Hak Pekerja Outsourcing Berdasarkan Asas Keadilan", Jurnal Yuridis, Vol. 3 No. 2 tahun 2016, Universitas Pembangunan Nasional "Veteran" Jakarta.

Kunia Maharani, "Peran Negara Dalam Mewujudkan Hubungan Industrial Pancasila Yang Harmonis Menuju Kesejahteraan Pekerja”, Proceeding Fakultas Ekonomi, 2013,Universitas STIKUBANK.

Mustari dan A. Nuruliah M., "Hak Atas Pekerjaan Dan Upah Yang Seimbang”, SUPREMASI : Jurnal Pemikiran, Penelitian Ilmu-Ilmu Sosial, Hukum dan Pengajarannya, Vol. 11 No. 1 tahun 2016, Universitas Negeri Makasar. 


\section{Peraturan Perundang-Undangan}

Undang-Undang Nomor 13 Tahun 2003 Tentang Ketenagakerjaan, Lembaran Negara Nomor 23 Tahun 2003

Undang-Undang Nomor 2 Tahun 2004 Tentang Penyelesaian Perselisihan Hubungan Industrial, Lembaran Negara Nomor 6 Tahun 2004

Undang-Undang Nomor 22 Tahun 1957 Tentang Penyelesaian Perselisihan Perburuhan, Lembaran Negara Nomor 42 Tahun 1957

Undang -Undang Nomor 12 Tahun 1964 Tentang Pemutusan Hubungan Kerja di Perusahaan Swasta, Lembaran Negara Nomor 93 Tahun 1964

\section{Putusan Pengadilan}

Putusan Pengadilan Hubungan Industrial pada Pengadilan Negeri Medan No. Perkara :155/Pdt.Sus-PHI/2015/PN.Mdn tanggal 7 Oktober 2015;

Putusan Pengadilan Hubungan Industrial pada Pengadilan Negeri Tanjung Pinang Perkara No: 42/G/2009/PHI.PN.TPI. tanggal 3 Maret 2010. pada Pengadilan Negeri Bandung Perkara No: 252/Pdt.Sus-PHI/2018/PN.Bdg, tanggal 17 April 2018;

Putusan Pengadilan Hubungan Industrial pada Pengadilan Negeri Tanjung Pinang Perkara No: 42/G/2009/PHI.PN.TPI. tanggal 3 Maret 2010.

Putusan Mahkamah Agung Republik Indonesia Perkara No: 502 K/Pdt.Sus/2009 tanggal 15 Juni 2010.

Putusan Mahkamah Agung Republik Indonesia Perkara No: 225 K/Pdt.Sus/2011 tanggal 15 Juni 2010;

Putusan Mahkamah Agung Republik Indonesia Perkara No: 743 K/Pdt.Sus/2010, tanggal 3 September 2010

Putusan Mahkamah Agung Republik Indonesia No. Perkara : $131 \mathrm{~K} /$ Pdt.Sus-

$\mathrm{PHI} / 2016,17$ Maret 2016 